\title{
A novel hepcidin-like in turbot (Scophthalmus maximus L.) highly expressed after pathogen challenge but not after iron overload
}

\author{
P. Pereiro, A. Figueras, B. Novoa * \\ Instituto de Investigaciones Marinas (IIM). CSIC. Eduardo Cabello, 6. 36208 Vigo, Spain \\ * Corresponding author. Tel.: +34 986214463; fax: +34 986292762 \\ E-mail address: virus@iim.csic.es
}

\begin{abstract}
Hepcidins are antimicrobial peptides with an important role in the host innate immunity. Moreover, it has been reported that mammalian hepcidins present a dual-function being a key regulator in the iron homeostasis. Here, we describe the coding sequence of a novel hepcidin-like peptide in turbot, Scophthalmus maximus. This molecule presents several differences with regard to the previously characterized hepcidin in this flatfish species and it has not the hypothetical iron regulatory sequence Q-S/I-H-L/I-S/A-L in the N-terminal region. Therefore we propose the existence of at least two types of hepcidin in turbot. Moreover, results revealed a higher variability in the mRNA sequences of the novel hepcidin compared with the other form. Constitutive expression of turbot hepcidins (Hepcidin-1 and Hepcidin-2) was analyzed in several tissues and as expected, both molecules were highly represented in liver. On the other hand, the effect of three different stimuli (bacterial or viral infection and iron overloading) in the level of hepcidin mRNA was also examined and a differential response to pathogens and iron was observed. Whereas both hepcidins were affected by pathogen challenge, only Hepcidin-1 was up-regulated after iron overloading. Therefore, this and other evidences suggest that these peptides could be involved in different functions covering the dual role of mammalian hepcidins.
\end{abstract}

Keywords: Turbot (Scophthalmus maximus), Fish, Innate immunity, Hepcidin, LEAP (liver-expressed antimicrobial peptide), Antimicrobial peptide, Bactericidal activity, Aeromonas salmonicida, VHSV, Iron metabolism 


\section{Introduction}

Antimicrobial peptides (AMPs) are cationic and amphipathic host defense peptides generally composed of 12-50 amino acids in length and produced by many organisms, including plants, invertebrates, and vertebrates [1]. A wide variety of AMPs have been described to date, presenting diversity in their sequence and structure [2], but all AMPs have in common their capacity to disrupt lipidic membranes in order to kill or inhibit the proliferation of microbes [3] and in some cases, inhibit DNA or protein synthesis [4]. Moreover, several AMPs posses immunomodulatory properties. They can act as chemokines or regulate the chemokine production, participate in the recruitment, maturation and activation of immune cells, as well as act as powerful anti-inflammatory or pro-inflammatory molecules [5-8].

Hepcidin is one of these multifunctional peptides. It was discovered for the first time as a cysteine-rich peptide composed by 25 amino acids in human blood and named LEAP1 (liver-expressed antimicrobial peptide) because its expression was predominantly detected in liver [9]. In addition to its bactericidal activity, hepcidin is also implicated in immunomodulatory functions and iron metabolism [10-18]. To our knowledge, the only mammal presenting two hepcidin genes in the genome is the mouse [10]. However, two or more hepcidin genes have been identified in several bony fish [19-26], with different degrees of sequence divergence. There are evidences suggesting that murine hepcidins (hepc1 and hepc2) perform different functions, given that only hepc1 seems to be involved in iron metabolism [27]. In fish, the different roles of hepcidin peptides still remain less clear.

Previously to our study, one hepcidin gene from turbot (Scophthalmus maximus) had been characterized [28]. In the present work, several Expressed Sequence Tags (ESTs) presenting homology to an "Antimicrobial peptide precursor" were analyzed and a novel hepcidin-like antimicrobial peptide was characterized in turbot. In addition, the constitutive expression of both hepcidins was analyzed in several tissues and the response to bacterial or viral infections and iron overload was also examined. On the basis of the obtained results, a potential role of turbot hepcidins is proposed.

\section{Materials and Methods}

\subsection{Animals}


Juvenile turbot (average weight $2.5 \mathrm{~g}$ ) were obtained from a commercial fish farm (Insuiña S.L., Galicia, Spain). Animals were maintained in 500 L fiberglass tanks with a re-circulating saline-water system with a light-dark cycle of $12: 12 \mathrm{~h}$ at $18{ }^{\circ} \mathrm{C}$ and fed daily with a commercial diet (LARVIVA-BioMar, France). Prior to experiments, fish were acclimatized to laboratory conditions for 2 weeks. Fish care and challenge experiments were reviewed and approved by the CSIC National Committee on Bioethics.

\subsection{ESTs analysis}

ESTs presenting similarity to an "Antimicrobial Peptide precursor" were obtained from a turbot sequencing assays performed by Pardo et al. [29] and from a high-throughput sequence analysis of turbot transcriptome using 454-pyrosequencing performed in our laboratory. The ESTs alignment was performed using ClustalW [30] and a contig was constructed using CAP3 sequence assembly program [31]. The sequence was translated from nucleotide to amino acid sequence using the translation tool from ExPasy [32] and was submitted to Blastp (http://blast.ncbi.nlm.nih.gov/Blast.cgi) for detecting homologies with other proteins. A comparison with other hepcidin proteins was performed for determining if this sequence represents the full-length coding sequence. According to the classification of hepcidin peptides performed by Hilton \& Lambert [33] we propose the nomenclature of Hepcidin-1 (Hep-1) for the molecule described by Chen et al. [28] and Hepcidin-2 (Hep-2) for the novel AMP identified in the present work, and they will be named accordingly in this paper.

\subsection{Analysis of sequence variability of both turbot hepcidins}

Total RNA was extracted from a pool composed by head kidney from 4 turbot intraperitoneally stimulated with the pathogen bacteria Aeromonas salmonicida subsp. salmonicida $\left(5.5 \times 10^{5} \mathrm{CFU} /\right.$ fish) using TRIzol $($ (Invitrogen) in accordance with instructions provided by the manufacturer in combination with the RNeasy mini kit (Qiagen) for RNA purification after DNase treatment (RNase-free DNase set, Qiagen). Quantity of the total purified RNA was determined using the spectrophotometer Nanodrop ND-1000. The reverse transcription was performed with the SuperScript II Reverse Transcriptase (Invitrogen) using $0.5 \mu \mathrm{g}$ of RNA and following the manufacturer indications. 
In order to determine if Hepcidin-1 and Hepcidin-2 presented variations in the sequence, specific primers were designed to amplify the open reading frame (ORF) (Table 1). The amplifications were performed in a $25 \mu$ l total volume containing $10 \mu 1$ of ultrapure water (Sigma-Aldrich), $12 \mu 1$ of 2x PCR Master Mix (Fermentas), $1 \mu 1$ of each specific primer $(10 \mu \mathrm{M})$ and $1 \mu 1$ of cDNA. PCR conditions consisted on an initial denaturation for $5 \mathrm{~min}$ at $94^{\circ} \mathrm{C}, 30$ cycles of denaturation at $94^{\circ} \mathrm{C}$ for $30 \mathrm{~s}$, annealing at $54^{\circ} \mathrm{C}$ for $30 \mathrm{~s}$, elongation at $72^{\circ} \mathrm{C}$ for $1 \mathrm{~min}$ and a final extension for $7 \mathrm{~min}$ at $72^{\circ} \mathrm{C}$ in a GeneAmp® PCR System 2700 thermocycler (Applied Biosystems). The PCR products were analyzed on a 1.5\% agarose gel stained with ethidium bromide under UV light using the Gel Doc XR system and the Quantity one program (Bio-Rad, Hercules, Ca). 3 $\mu \mathrm{l}$ of PCR product were linked into $\mathrm{pCR} \AA 2.1$ plasmid vector (Invitrogen) for its cloning following the protocol instructions and One Shot ${ }^{\circledR}$ TOP $10 F^{\prime}$ competent cells (Invitrogen) were transformed using the plasmid. Bacteria were cultured on $\mathrm{LB} / \mathrm{Ampicillin} / \mathrm{IPTG} / \mathrm{X}-\mathrm{Gal}$ plates during 24 hours at $37^{\circ} \mathrm{C}$ and the bacterial colonies were selected by the blue-white screening method. 25 positive clones for each hepcidin were selected and the insert was amplified using the M13 vector specific primers (M13F: 5'-GTAAAACGACGGCCAG-3', M13R: 5'-CAGGAAACAGCTATGAC-3). PCR was performed as mentioned above. cDNA sequencing was conducted using an automated ABI 3730 DNA Analyzer (Applied Biosystems, Inc. Foster City, CA, USA). For each hepcidin, the 25 sequences were compared using ClustalW [30] in order to detect sequence variations.

The consensus sequences for both hepcidin were obtained using CAP3 software [31] that corresponded to the most prevalent clone. In each case, sequences were aligned for identifying the conserved regions between both turbot hepcidins. Sequence similarity and identity scores were calculated with the software BioEdit [34] using the BLOSUM62 matrix. Prediction of cleavage sites for the signal peptide and the prodomain was performed using ProP 1.0 server [35]. The molecular weight and isoelectric point of the mature peptide were determined using the Compute $\mathrm{pI} / \mathrm{Mw}$ tool from ExPASy [32] and the estimated half-life of both peptides was predicted using ProtParam tool too from ExPASy [32].

\subsection{Genomic organization}

Genomic DNA was extracted from healthy turbot muscle using the Phenol-Chloroform method [36]. In order to determine the presence of introns in the genomic sequence of 
the novel Hepcidin-2 the amplification was performed with the same primers used for the confirmation of the full-length coding sequence (Table 1). One $\mu \mathrm{g}$ of DNA was used as template for PCR amplification. The elongation step on each cycle was 90 seconds for the genomic sequence. Four positive clones were sequenced. Exon-intron junctions were deduced using Wise2 software (http://www.ebi.ac.uk/Wise2/programming).

\subsection{Phylogenetic analysis}

Amino acid sequences of turbot hepcidins were compared with those from other fish and vertebrates (whole prepropeptides). Sequences employed for the alignment and their GenBank accesion numbers were: Ictalurus punctatus (NP_001187130), Siniperca chuatsi (ACO88905), Salmo salar (AAO85553), Oncorhynchus mykiss (ADU85830), Sparus aurata (CAO78619), Morone chrysops (AAM28440), Danio rerio (AAN10302), Dicentrarchus labrax (AAZ85124), Paralichthys olivaceus (BAE06234) and (BAE06235), Puntius sarana (CAZ68137), Crocodylus siamensis (ADA68357), Xenopus tropicalis (NP_001090729) and (ABL75284), Homo sapiens (NP_066998), Pan troglodytes (ABU75211), Equus caballus (NP_001161799), Mus musculus (NP_115930) and Rattus norvegicus (NP_445921). Multiple sequence alignment was performed using the T-Coffee server [37] in regular computation mode and using the t_coffee_msa multiple alignment method and phylogenetic tree was drawn using Mega 4.0 software [38] Neighbor-Joining algorithm [39] was used as clustering method, the distances matrix was computed using Poisson correction method and all positions containing alignment gaps and missing data were eliminated. Statistical confidence of the phylogenetic analysis was assessed by performing 1,000 bootstrap replicates.

\subsection{Constitutive expression of hepcidins}

Eight different tissues (kidney, spleen, gill, liver, intestine, heart, brain and muscle plus skin) were removed from 20 healthy fish in order to examine the constitutive expression of both hepcidins. Equal amounts of the same tissue from four fish were pooled, obtaining 5 biological replicates for each tissue (4 turbot/replicate). Total RNA was extracted and cDNA was synthesized as mentioned above. Hepcidin expression profiles were determined using Real-time quantitative PCR. Specific PCR primers (Table 1) were designed using the Primer3 program [40] and their amplification efficiency was calculated using seven serial five-fold dilutions of head kidney cDNA from 
unstimulated turbot with the Threshold Cycle $\left(\mathrm{C}_{\mathrm{T}}\right)$ slope method [41]. Individual realtime PCR reactions were carried out in $25 \mu 1$ reaction volume using $12.5 \mu 1$ of SYBR ${ }^{\circledR}$ GREEN PCR Master Mix (Applied Biosystems), $10.5 \mu 1$ of ultrapure water (SigmaAldrich), $0.5 \mu 1$ of each specific primer $(10 \mu \mathrm{M})$ and $1 \mu 1$ of five-fold diluted cDNA template in MicroAmp® optical 96-well reaction plates (Applied Biosystems). All reactions were performed using technical triplicates in a 7300 Real-Time PCR System thermocycler (Applied Biosystems) with an initial denaturation $\left(95^{\circ} \mathrm{C}, 10 \mathrm{~min}\right)$ followed by 40 cycles of a denaturation step $\left(95^{\circ} \mathrm{C}, 15 \mathrm{~s}\right)$ and one hybridization-elongation step $\left(60^{\circ} \mathrm{C}, 1 \mathrm{~min}\right)$. An analysis of melting curves was performed for each reaction. Relative expression of Hepcidin-1 and Hepcidin-2 was normalized using the Elongation Factor-1 alpha as reference gene, which was constitutively expressed and not affected by the experimental treatments, and calculated using the Pfaffl method [41]. Fold-change units were calculated by dividing the normalized expression values for each tissue by the normalized expression values obtained in the organ presenting the lower expression level for each hepcidin. The relative rates of turbot hepcidin types expressed in the different tissues were calculated taking into account the normalized values of each hepcidin in the same tissue.

\subsection{Expression of hepcidins under different stimuli}

In order to study the transcriptional induction of turbot hepcidins several experimental stimulations were performed. Three kinds of stimuli were used: bacterial or viral infections and iron overloading. Fish were divided into five groups, composed of 80 fish each. Turbot belonging to one group were injected intraperitoneally with $50 \mu 1$ of an Aeromonas salmonicida subsp. salmonicida (strain VT $45.1 \mathrm{WT})$ suspension $\left(5.5 \times 10^{5}\right.$ CFU/fish), other group was inoculated with a Viral Haemorrhagic Septicaemia Virus (VHSV- strain UK-860/94) suspension (1.2 x $10^{5} \mathrm{TCID}_{50} /$ fish) and eighty turbot using Iron-dextran (Sigma Chemical Co., St. Louis, MO, USA) (0.1 mg/fish). The Gramnegative bacteria and Iron-dextran were resuspended in 1x Phosphate Buffered Saline (PBS 1x) and the viral suspension using Eagle's minimum essential medium (MEM, Gibco) supplemented with $2 \%$ fetal bovine serum (FBS), penicillin (100 IU/ml) (Invitrogen) and streptomycin $(100 \mu \mathrm{g} / \mathrm{ml})$ (Invitrogen). Therefore, two control groups were necessary, one injected intraperitoneally with $50 \mu 1$ of PBS 1x and another one using MEM $+2 \%$ FBS $+\mathrm{P} / \mathrm{S}$. Head kidney and liver from twenty fish belonging to each 
experimental group were removed at different sampling points (3, 8, 24 and 72 hours). For each sampling point and treatment, equal amounts of each tissue from four turbot were pooled, constituting five biological replicates for head kidney and other five for liver (4 turbot/replicate). Moreover, in order to determine if hepcidins expression was iron dose-dependent, thirty-six fish were divided into 3 batches of 12 individuals each and every group was injected with a different Iron-dextran dose $(0.1 \mu \mathrm{g} /$ fish, 0.1 $\mathrm{mg} /$ fish and $0.5 \mathrm{mg} /$ fish). Head kidney and liver were removed at 24 hour after stimulation and the tissues from four turbot were pooled, obtaining 3 biological replicates. Total RNA was extracted and cDNA was synthesized as mentioned above and amplification was carried out using the same protocol previously described.

\subsection{Statistical analysis}

Expression results were represented graphically as the mean \pm the standard deviation of the biological replicates. In order to determine statistical differences, data were analyzed using the computer software package SPSS v.19.0. One-way ANOVA followed by Tukey's multiple comparison test of the means among the different time groups and between each time group and its corresponding control was performed. Differences were considered significant when $p<0.05$.

\section{Results}

\subsection{Molecular characterization of Hepcidin-2}

Hepcidin-1, previously identified in turbot [28], was composed of 90 amino acids, however, the deduced amino acid sequence of the new hepcidin form characterized in the present work consisted of 84 amino acids with a full-length coding sequence of 255 bp in length (Figure 1). Turbot Hep-2 exhibited cleavage sites for processing the immature peptide. A potential cleavage site for the signal peptide was predicted to be located between positions 24 and 25 (SAA-TF) and a motif for the propeptide cleavage was predicted between the residues $\mathrm{Arg}^{62}$ and Gly ${ }^{63}$. Consequently, the predicted prepropeptide consisted of a 24 amino acids signal peptide, a prodomain of 38 residues and a mature processed peptide of 22 amino acids. The predicted molecular weight of the mature peptide was $2365.87 \mathrm{Da}$ and the isoelectric point was 7.70. The estimated half-life for Hep-1 (0.8 hours in mammalian reticulocytes in vitro, $10 \mathrm{~min}$ in yeast or 10 
hours in Escherichia coli) was shorter than the half-life for Hep-2 (30 hours in mammalian reticulocytes in vitro, $>20$ hours in yeast or $>10$ hours in E. coli).

\subsection{Patterns of nucleotide and amino acid variability in the sequence of both hepcidins} The comparison of the 25 sequences of the previously described Hepcidin-1 revealed only a single nucleotide polymorphism (SNP) in the mature peptide at the nucleotide position 241 of ORF: 5/25 of the sequences presented an A and 20/25 a T which coded for a different amino acid in the position 81 (Asn or Tyr, respectively). Hepcidin-2 however, presented a higher polymorphism showing several nucleotide substitutions. The presence of these changes resulted more prevalent in the mature peptide region, affecting in some cases the presence of the fifth cysteine (Figure 1). The amino acid sequences of turbot Hep-2 were submitted to GenBank under accession numbers JQ219831-9.

The alignment between both hepcidin consensus sequences revealed numerous differences in the amino acid sequences, but the eight Cys residues were relatively well conserved with some exception as it was mentioned above (Figure 2). The identity and similarity scores between both hepcidins were $51.1 \%$ and $66.67 \%$, respectively. Interestingly, only Hep-1 presents the hypothetical iron regulatory sequence Q-S/I-H$\mathrm{L} / \mathrm{I}-\mathrm{S} / \mathrm{A}-\mathrm{L}$ in the N-terminal region of the mature peptide.

\subsection{Genomic organization}

The hepcidin- 2 genomic structure was composed by 3 exons and 2 introns. Intron 1 was $85 \mathrm{bp}$ in length whereas intron 2 was $132 \mathrm{bp}$ in length. The exon 1 contained the signal peptide region and 12 nucleotides belonging to the prodomain, the exon 2 was entirely composed by a prodomain sequence and the exon 3 contained 24 nucleotides of the prodomain and the mature peptide nucleotide sequence (Figure 3). Turbot Hep-2 gene organization followed the same pattern of hepcidin genes from other vertebrates. Interestingly, partially spliced Hep-1 transcripts retaining the first intron were identified, but not in Hep-2. The genomic sequence of turbot Hep-2 was submitted to GenBank under accession number JQ219840.

\subsection{Phylogenetic analysis}

Protein alignment with other hepcidin sequences from fish species and other vertebrates showed that hepcidins are relatively well conserved among the vertebrates, specially the 
eight cysteine residues in the mature peptide (Figure 4A). The alignment revealed that hepcidin sequence similarity among fish species is higher than between fish and the other vertebrates. Moreover, notable variations in the mature peptide length are present among species and between hepcidin types of the same organism, as occurs in Paralichthys olivaceus and Xenopus tropicalis, as well as in S. maximus.

Phylogenetic analysis placed the fish hepcidins in a separated cluster from the other vertebrates (Figure 4B). Danio rerio and Puntius sarana are cyprinids, and the hepcidins from these species were grouped in a branch. The salmonid proteins appeared also forming a separate group within the cluster of fish. Hepcidins from the perciforms Sparus aurata, Siniperca chuatsi, Dicentrarchus labrax and Morone chrysops also grouped together. Scophthalmus maximus Hep-1 was placed in the same cluster of Paralichthys olivaceus Hep-JF2, the other flatfish used in the analysis; Scophthalmus maximus Hep-2 was grouped within the same branch of Paralichthys olivaceus HepJF1. Between turbot Hep-1 and Japanese flounder Hep-JF2 the identity was 79.1\% and the similarity was $83.5 \%$, and the values between turbot Hep-2 and Japanese flounder Hep-JF1 were $58.3 \%$ and $74.1 \%$, respectively.

\subsection{Constitutive expression of both Hepcidins}

Hepcidin-1 and Hepcidin-2 mRNA were detected in all tissues tested in healthy turbot. Fold-change for each tissue was referenced to the brain ( 1 fold), the organ presenting the lower expression level for both transcripts. Hep-1 was predominantly expressed in the liver (about 150 fold-change), a moderate level was detected in kidney, intestine and spleen (7-11 fold) and the lowest expression in gill, muscle plus skin, heart and brain ( $<2$ fold) (Figure 5A). Hep-2 was also predominantly detected in liver (about 2255 foldchange); an elevated presence of transcripts was also observed in intestine (about 440 fold) and kidney (about 100 fold); the other tissues presented a lower fold-change of 20 fold) (Figure 5B). The relative rates of turbot hepcidin types expressed in the different tissues showed a higher presence of Hep-2 mRNA in most of the tissues tested, with the exception of muscle/skin and brain. The highest proportion of Hep-2 with regard to Hep-1 was observed in intestine and the larger proportion of Hepcidin-1 compared with Hep-2 was obtained in brain (Figure 5C).

\subsection{Hepcidin expression after bacterial or viral infections and iron overload.}


Regarding hepcidin expression after immunostimulation using the fish-pathogenic bacteria Aeromonas salmonicida subsp. salmonicida, Hep-1 increased its expression significantly in head kidney at $3 \mathrm{~h}$ post-infection (p.i.) (2.5 fold), and reached the larger fold-change at $24 \mathrm{~h}$ p.i. ( 35 fold). In liver, there were not significant differences compared to PBS-injected control at $3 \mathrm{~h}$ p.i., but the level of Hep-1 mRNA exhibited an increase at $8 \mathrm{~h}$ after bacterial challenge ( 2.6 fold), and the level remained more elevated at 24 and 72 h p.i. (about 5 fold) (Figure 6A). Hepcidin-2 expression was significantly inhibited in head kidney at $3 \mathrm{~h}$ p.i. (fold-change value of 0.2 ), but at $8 \mathrm{~h} \mathrm{p.i.} \mathrm{the} \mathrm{fold-}$ change reached an increase of 10 fold and at $24 \mathrm{~h}$ after bacterial stimulation the level increased until 700 fold with regard to the control group. In liver, a significant upregulation of Hep-2 was observed at $24 \mathrm{~h}$ post-injection (about 2.8 fold) and the level remained in the same value at $72 \mathrm{~h}$. (Figure 6B). Interestingly, although the constitutive expression of hepcidin was predominant in liver, its induction after Aeromonas salmonicida subsp. salmonicida challenge was more pronounced in head kidney. Moreover, in head kidney the highest induction was for Hep-2 and in liver was reached for Hep-1.

Hep-1 expression was drastically reduced after viral stimulation with VHSV at $8 \mathrm{~h}$ p.i. in head kidney (fold-change value of 0.15 ) but at $72 \mathrm{~h}$ the expression level was significantly up-regulated (2.6 fold). In liver this increase occurs earlier, at $24 \mathrm{~h}$ after VHSV infection with the same fold-change value ( 2.6 fold) and at $72 \mathrm{~h}$ the increase with regard to the MEM $+2 \% \mathrm{FBS}+\mathrm{P} / \mathrm{S}$-injected control group was 3.5 fold (Figure 7A). As occurs with Hep-1, Hep-2 transcripts were highly down-regulated in head kidney at $8 \mathrm{~h}$ after viral stimulation (fold-change value of 0.01 ) but it was strongly upregulated at $72 \mathrm{~h}$ (more than 42 fold). In liver a significant inhibition was also detected after VHSV injection at $8 \mathrm{~h}$ (about 0.7 fold-change value), but an important increase of Hep-2 mRNA was observed after $72 \mathrm{~h}$ (Figure 7B). The highest increase of hepcidin expression also occurred for Hep-2 in head kidney.

The administration of Iron-dextran $(0.1 \mathrm{mg} /$ fish $)$ to juvenile turbot for generating an iron overload also affected the expression of hepcidins. Hep-1 transcripts were inhibited in head kidney and liver at $3 \mathrm{~h}$ after stimulation. In head kidney an up-regulation was detected at $72 \mathrm{~h}$ (3.1 fold) and in liver at $24 \mathrm{~h}$ (4.6 fold), remaining high values until 72 $\mathrm{h}$ (7 fold) (Figure 8A). A significant initial inhibition of Hep-2 level was also detected in head kidney at $3 \mathrm{~h}$ after iron administration with regard to PBS-injected control. No significant differences were found at subsequent sampling points. During the 
experimental time course, iron overloading did not affect Hep-2 mRNA level in liver (Figure 8B). Moreover, hepcidin expression was Iron-dextran dose dependent at $24 \mathrm{~h}$ after administration. A significant up-regulation was detected for Hep-1 with the lowest iron dose $(0.1 \mu \mathrm{g} /$ fish $)$ in head kidney (about 1.8 fold), but this increase disappeared with the intermediate dose $(0.1 \mathrm{mg} /$ fish $)$ and a notable inhibition at concentrations of 0.5 $\mathrm{mg}$ /fish was observed. In liver the response was opposite, exhibiting significant elevation of Hep-1 expression with higher iron doses (Figure 9A). Regarding Hep-2, head kidney showed an inhibition in mRNA level, and this reduction was more pronounced using more concentrated solution (Figure 9B). The same tendency was observed in liver, but differences were non-significant.

\section{Discussion}

Mammalian hepcidins are multifunctional molecules involved in numerous immune processes but, on the other hand, present a pivotal role in iron metabolisms [10-18]. A new hepcidin-like antimicrobial molecule from the flatfish Scophthalmus maximus was characterized in this study. Turbot Hep-2 presents several differences in the sequence and length of the three regions (signal peptide, prodomain and mature peptide) with regard to the previously described turbot Hep-1. The identity score between both turbot hepcidins suggests that there are at least two different types of hepcidin in turbot. Genetic duplication and further mutation of AMPs has been suggested as a molecular strategy in the evolution of these molecules [42]. There are evidences for positive Darwinian selection on antimicrobial peptides [43], and more specifically in hepcidinlike variants of pleuronectiform and perciform [44]. The prevalence of mutations is usually most elevated in the mature peptide region compared to the signal sequence and prodomain [45]. Turbot Hep-2 presents amino acid substitutions in the three regions conforming the prepropeptide, but the prevalence of SNPs is more pronounced in the mature peptide, that is, the active region. This genetic variation due to accelerated evolutionary rates might possibly be directed by pathogens when the host is exposed to new environments $[44,46]$. As it was proposed for the complement component C3 in teleost fish, the presence of different isoforms would allow these animals to expand their innate immune recognition capabilities [47]. It could be interesting to investigate whether changes in the mature peptide region generate diversification or specialization in the functions of turbot hepcidins and affect their ability for bacterial inhibition. 
In a similar way to other vertebrates, Hep-2 genomic organization is composed by three exons and two introns. As occurs in the majority of fish hepcidins, the first intron is larger than the second intron [19,20,22,28,48-54] with some exception [55]. Moreover, introns of turbot Hep-2 (85 and 132 bp) are shorter that introns of turbot Hep-1 (114 and $172 \mathrm{bp}$ ). A curious phenomenon of truncated hepcidin transcripts retaining the first intron was observed in some turbot Hep-1 transcripts. This event was also reported previously in rockbream hepcidins [52], where a significant increase of these partial spliced transcripts occurred after bacterial challenge or iron overload. In our work, we also cloned the turbot hepcidin from turbot previously stimulated with $\mathrm{A}$. salmonicida. The resultant forms presented a stop codon in the intron and, as a result, these transcripts may not be translated into functional hepcidin. Cho et al. [52] proposed that the massive induction of transcripts causes a reduction in the specificity of the splicing process in immature transcripts, but further analysis will be necessary for determining the incomplete processing of these mRNA.

A phylogenetic analysis of hepcidins in vertebrate species revealed a strong conservation of the eight cysteine residues in the mature peptide region, conforming four disulphide bonds characteristic of hepcidins. Interestingly, Japanese flounder HepJF1 only presents six cysteines. Moreover, one mutation detected in turbot Hep-2 can affect the presence of the fifth cysteine. As was reported by Nemeth et al. [56] for human hepcidin, altered disulfide-bonding pattern allow a nearly full activity of the peptide in vitro. It is possible that in the case of turbot Hep-2 functionality also remains. Fish hepcidins formed a separated cluster from de other vertebrate hepcidins and within the fish group the similarities were higher among species belonging to the same order. The identities and similarities between turbot Hep-1 and Japanese flounder Hep-JF2 and between turbot Hep-2 and Japanese flounder Hep-JF1 were higher than the identity and similarity between both turbot hepcidins. These results suggest that Hep-1 and Hep-2 from turbot could have different functions.

As expected, both turbot hepcidins were abundantly expressed in liver. Our results for Hep-1 distribution differ in some tissues with those obtained by Chen et al. [28] using RT-PCR which could be due to differences in the age of the animals (adult fish or juveniles) or to the used technology (real-time quantitative PCR is more sensitive than the conventional PCR used by these investigators). The relative proportion of hepcidin types showed a predominant presence of Hep-2 in all tissues tested with the exception 
of muscle plus skin and brain. This tissue-specific pattern of hepcidin mRNA in healthy juvenile turbot is in agreement with what it has been reported for other fish hepcidins $[20-22,52,57]$.

Turbot hepcidins were significantly induced after bacterial challenge with Aeromonas salmonicida. Despite the highest presence of hepcidin transcripts in liver, the fold increase relative to control fish was more pronounced in head kidney for Hep-1 and Hep-2. Our findings contrast with the results obtained by Chen et al. [28] which observed a significantly up-regulation of turbot Hep-1 expression at 24, 48, 72 and $96 \mathrm{~h}$ after infection with Listonella anguillarum in liver and spleen but not in head kidney. Another experimental assay revealed a significant up-regulation of hepcidin transcripts in liver and spleen but not in head kidney after Listonella anguillarum infection in gilthead seabream [53]. Interestingly, Japanese flounder hepcidins were differentially affected by lipopolysaccharide (LPS) injection; Hep-JF1 expression was induced in liver but not in kidney and Hep-JF2 expression was up-modulated in kidney but not in liver [20]. Bo et al. [26] observed an increase in both Oryzias melastigma hepcidins (OM-hep1 and OM-hep2) in liver and spleen after Vibrio parahaemolyticus administration and, as in our case, the response was faster in the case of type 1 hepcidin. Induction of hepcidin expression after bacterial or LPS administration could varies as a function of the type of hepcidin in species presenting more than one form. There is scarce information about the response of fish hepcidin peptides to viral infections and the studies are usually based in the effect of Polyriboinosinic polyribocytidylic acid (poly I:C) injection, which is a synthetic nucleic acid widely used in the study of the immune response to double-stranded RNA virus $[21,55,58]$. These reports have shown that fish hepcidins can be induced by poly I:C. Cho et al. [52] analyzed the expression of hepcidin peptides in rockbream after iridovirus infection and detected an up-regulation of hepcidins in liver, intestine, kidney and spleen at 10 days post-challenge and the increase was especially high in liver. Hepcidin up-regulation was also reported in gilthead seabream after VHSV inoculation at 4 and $72 \mathrm{~h}$ post-injection in liver, head kidney and spleen [53]. Our analysis about the modulation of turbot hepcidins after VHSV challenge revealed an initial inhibition of Hep-1 and Hep-2 expression in head kidney and liver, but at $72 \mathrm{~h}$ after infection an up-regulation of both hepcidins was detected. This initial down-regulation of hepcidin levels could be related to increased levels of Tumor necrosis factor (TNF)- $\alpha$ after VHSV infection at 3, 8 and 
$24 \mathrm{~h}$ but not at $72 \mathrm{~h}$ post-challenge (data not shown). It has been found that TNF inhibits the release of iron from macrophages inducing hypoferremia and consequently hepcidin levels may be affected $[59,60]$, but more research is needed to clarify this issue. Moreover, in vitro analysis will be necessary in order to determine if hepcidin peptides can inhibit viral replication, as was reported for marine medaka Om-hep1 against White Spot Syndrome Virus (WSSV) [61].

On the other hand, hepcidin is the main negative regulator in iron homeostasis in mammals [10-12]. Nicolas et al. [11] concluded in their study using upstream stimulatory factor-2 (USF2) gene knock-out mice that hepcidin was a negative regulator of iron uptake at the intestinal level and of the iron release from macrophages. When the level of iron in the organisms is high, the expression of hepcidin is elevated. Hepcidin acts by direct binding to its cellular receptor ferroportin, the unique known iron transporter on the cell membrane, and this receptor is internalized and degraded at lysosomal level [62]. As consequence, the iron absorption from enterocytes to plasma and its exportation from macrophages get canceled. Moreover, hepcidin reduces the iron available for pathogen proliferation since bacteria require iron as a growth-essential nutrient [63] and an efficient viral replication needs an iron-replete host [64]. The role of fish hepcidins in iron homeostasis remains still unclear. There are evidences about the conservation of the dual role of hepcidins in fish. Rodrigues et al. [51] detected an up-regulation of sea bass hepcidin level in liver at 4 days after experimental treatment using Iron-dextran. Huang et al. [21] studying the effect of an iron overload in the expression of the three different hepcidins from tilapia have suggested that these different types have their own functions in different organs for regulating iron metabolisms, since each hepcidin responds to the iron administration in different tissues. With regard to Japanese flounder, gene expression of Hep-JF1 in liver was down-regulated during experimental iron overloading (at 1,2 or 3 weeks after treatment), whereas Hep-JF2 expression was not affected in liver but its expression in kidney increased after injection of iron-dextran [20]. Our results showed a possible role of Hep-1 in iron homeostasis in head kidney and liver, since a significant increase in the expression level was detected in both tissues. However, the gene expression of Hep-2 was not up-regulated during the experimental assay. On the other hand, a significant initial inhibition was detected for Hep-1 in head kidney $(3 \mathrm{~h})$ and liver ( 3 and $8 \mathrm{~h})$ and for Hep-2 in head kidney (3 h). The reason for this initial down-regulation of hepcidin 
transcripts is unknown and further studies are necessary in order to understand this process. Moreover, increasing doses of Iron-dextran significantly reduced the Hep-1 and Hep-2 expression in head kidney, but the Hep-1 levels in liver were progressively increased using higher doses of Iron-dextran.

The overall results of this paper seem to suggest that Hep-1 is more involved in body iron regulation, whereas the role of Hep-2 would be a more specialized one in the immune defense. Furthermore, the higher variability in the amino acid sequence of Hep2 may be an evolutionary mechanism for the recognition of a diverse range of microbes and the longer half-life with regard to Hep-1 could favor the elimination of pathogens. Other evidence supporting this hypothesis is the presence of the Q-S/I-H-L/I-S/A-L sequence in the $\mathrm{N}$-terminal region of the mature peptide. As was proposed by Robertson et al [23] the existence of these amino acids could be related with an iron-regulatory function. There are three hepcidins in Oreochromis mossambicus and one of those hepcidins (TH2-3) possesses the characteristic sequence and the other two peptides lack these amino acids; interestingly, tilapia hepcidin TH2-3 seems be the peptide implicated in iron regulation in liver [21]. Paralichthys olivaceus possesses two types of hepcidin, and Hep-JF2 contains a similar N-terminal sequence, H-I-S-H-I-S-M. As was reported for tilapia TH2-3, only Japanese flounder Hep-JF2 was up-regulated in head kidney after iron overloading [20], Turbot Hep-1 contains the typical $\mathrm{N}$-terminal sequences and, as occurs with their homolog in P. olivaceus, their expression was up-regulated after Iron-dextran administration, whereas the level of Hep-2 (hepcidin lacking this sequence) remained low.

In conclusion, a novel hepcidin-like antimicrobial peptide was characterized in the flatfish Scophthalmus maximus, presenting numerous differences in the sequence with the previously described hepcidin. Our results on the expression of both hepcidins suggest that Hep-1 and Hep-2 may have different functions, since their transcriptional modulation was different, the variability in the sequence and the half-life was higher in Hep-2 compared to Hep-1 and the presence of the Q-S/I-H-L/I-S/A-L sequence in the $\mathrm{N}$-terminal region may be a marker to identify those most involved hepcidin in iron metabolism function. Hence, the dual role of mammalian hepcidins could be divided between both peptides in turbot. Further studies will be needed in order to elucidate this question.

\section{Acknowledgements}


We want to thank the funding from the project CSD2007-00002 "Aquagenomics" of the program Consolider-Ingenio 2010 from the Spanish Ministerio de Ciencia e Innovación.

\section{References}

[1] Hancock REW. Cationic peptides: effectors in innate immunity and novel antimicrobials. Lancet Infect Dis 2001;1:156-64.

[2] Mookherjee N, Hancock REW. Cationic host defence peptides: Innate immune regulatory peptides as a novel approach for treating infections. Cell Mol Life Sci 2007;64:922-33.

[3] Lai Y, Gallo RL. AMPed up immunity: how antimicrobial peptides have multiple roles in immune defense. Trends Immunol 2009;30:131-41.

[4] Yeaman MR, Yount NY. Mechanisms of antimicrobial peptide action and resistance. Pharmacol Rev 2003;55:27-55.

[5] Oppenheim JJ, Bigagyn A, Kwak LW, Yang D. Roles of antimicrobial peptides such as defensins in innate and adaptive immunity. Ann Rheum Dis 2003;62:17-21.

[6] Biragyn A. Defensins - Non-antibiotic use for vaccine development. Curr Protein Pept Sci 2005;6:53-60.

[7] Bowdish DME, Davidson DJ, Hancock REW. Immunomodulatory properties of defensins and cathelicidins. Curr Top Microbiol Immunol 2006;306:27-66.

[8] Nicholls EF, Madera L, Hancock REW. Immunomodulators as adjuvants for vaccines and antimicrobial therapy. Ann NY Acad Sci 2010;1213:46-61.

[9] Krause A, Neitz S, Mägert HJ, Schulz A, Forssmann WG, Schulz-Knappe P, et al. LEAP-1, a novel highly disulfure-bonded human peptide, exhibits antimicrobial activity. FEBS Lett 2000;480:147-50.

[10] Pigeon C, liyin G, Courselaud B, Leroyer P, Turlin B, Brissot P, et al. A new mouse liver-specific gene, encoding a protein homologous to human antimicrobial peptide hepcidin, is overexpressed during iron overload. J Biol Chem 2001; 276:7811-9. 
[11] Nicolas G, Bennoun M, Devaux I, Beaumont C, Grandchamp B, Kahn A, et al. Lack of hepcidin gene expression and severe tissue iron overload in upstream stimulatory factor 2 (USF2) knockout mice. PNAS 2001;98:8780-5.

[12] Ganz T. Hepcidin, a key regulator of iron metabolism and mediator of anemia of inflammation. Blood 2003; 102:783-8.

[13] Ashrafian H. Hepcidin: the missing link between hemochromatosis and infections. Infect Immun 2003;71:6693-700.

[14] Rossi E. Hepcidin - the iron regulatory hormone. Clin Biochem Rev 2005;26:47-9.

[15] Kemna E, Pickkers P., Nemeth E, van der Hoeven H, Swinkels D. Time-course analysis of hepcidin, serum iron, and plasma cytokine levels in human injected with LPS. Blood 2005;106:1864-6.

[16] Hugman A. Hepcidin: an important new regulator of iron homeostasis. Clin Lab Haematol 2006;28:75-83.

[17] De Domenico I, Zhang TY, Koening C, Branch RW, London N, Lo E, et al. Hepcidin mediates trasncriptional changes that modulate acute cytokine-induced inflammatory responses in mice. J Clin Invest 2010;120:2395-405.

[18] Rajanbabu V, Pan CY, Lee SC, Lin WJ, Lin CC, Li CL. Tilapia hepcidin 2-3 peptide modulates lipopolysaccharide-induced cytokines and inhibits tumor necrosis factor-alpha through cyclooxygenase-2 and phosphodiesterase 4D. J Biol Chem 2010;285:30577-86.

[19] Shike H, Shimizu C, Lauth X, Burns JC. Organization and expression analysis of the zebrafish hepcidin gene, an antimicrobial peptide gene conserved among vertebrates. Dev Comp Immunol 2004;28:747-54.

[20] Hirono I, Hwang JY, Ono Y, Tomofumi K, Ohira T, Nozaki R, et al. Two different types of hepcidins from the Japanese flounder Paralichthys olivaceus. FEBS J 2005;272:5257-64.

[21] Huang PH, Chen JY, Kuo CM.Three different hepcidins from tilapia, Oreochromis mossambicus: Analysis of their expressions and biological functions. Mol Immunol 2007;44:1922-34. 
[22] Kim YO, Park EM, Nam BH, Kong HJ, Kim WJ, Lee SJ. Identification and molecular characterization of two hepcidin genes from black rockfish (Sebastes schlegelii). Mol Cell Biochem 2008; 315:131-6.

[23] Robertson LS, Iwanowicz LR, Marranca JM. Identification of centrarchid hepcidins and evidence that $17 \mathrm{~b}$-estradiol disrupts constitutive expression of hepcidin-1 and inducible expression of hepcidin-2 in largemouth bass (Micropterus salmoides). Fish Shellfish Immunol 2009;26:898-907.

[24] Martin-Antonio B, Jiménez-Cantizano R, Salas-Leiton E, Infante C, Machado M. Genomic characterization and gene expression analysis of four hepcidin genes in the redbanded seabream (Pagrus auriga). Fish Shellfish Immunol 2009;26:483-91.

[25] Zhou JG, Wei JG, Xu D, Cui HC, Yan Y, Ou-Yang ZL, et al. Molecular cloning and characterization of two novel hepcidins from orange-spotted grouper, Epinephelus coioides. Fish Shellfish Immunol 2011;30:559-68.

[26] Bo J, Cai L, Xu JH, Wang KJ, Au DWT. The marine medaka Oryzias melastigma - A potential marine fish model for innate immune study. Mar Pollut Bull 2011;63:26776.

[27] Lou DQ, Nicolas G, Lesbordes JC, Viatte L, Grimber G, Szajnert MF, et al. Functional differences between hepcidin 1 and 2 in transgenic mice. Blood 2004;103:2816-21.

[28] Chen SL, Li W, Meng L, Sha ZX, Wang ZJ, Ren GC. Molecular cloning and expression analysis of a hepcidin antimicrobial peptide gene from turbot (Scophthalmus maximus). Fish Shellfish Immunol 2007;22:172-81.

[29] Pardo BG, Fernández C, Millán A, Bouza C, Vázquez-López A, Vera M, et al. Expressed sequence tags (ESTs) from immune tissues of turbot (Scophthalmus maximus) challenged with pathogens. BMC Vet Res 2008;4:37.

[30] Thompson JD, Higgins DG, Gibson TJ. CLUSTAL W: improving the sensitivity of progressive multiple sequence alignments through sequence weighting, position specific gap penalties and weight matrix choice. Nucleic Acid Res 1994;22:4673-80.

[31] Huang X, Madan A. CAP3: A DNA sequence assembly program. Genome Res 1999;9:868-77. 
[32] Gasteiger E, Gattiker A, Hoogland C, Ivanyi I, Appel RD, Bairoch A. ExPASy: the proteomics server for in-depth protein knowledge and analysis. Nucleic Acid Res 2003;31:3784-88.

[33] Hilton KB, Lambert LA. Molecular evolution and characterization of hepcidin gene products in vertebrates. Gene 2008;425:40-8.

[34] Hall TA. BioEdit: a user-friendly biological sequence alignment editor and analysis program for Windows 95/98/NT. Nucleic Acids Symp Ser 1999;41:85-98.

[35] Duckert P, Brunak S, Blom N. Prediction of proprotein convertase cleavage sites. Protein Eng Des Sel 2004;17:107-12.

[36] Strauss WM. Preparation of genomic DNA from mammalian tissues. In: Ausubel FM, Brent R, Kingston R., Moore DD, Seidman JG, Smith JA, et al., editors. Current protocols in molecular biology, New York: John Wiley and Sons; 2000. p. 221-2.

[37] Notredame C, Higgins DG, Heringa J. T-Coffee, a novel method for fast and accurate multiple sequence alignment. J Mol Biol 2000; 302: 205-17

[38] Tamura K, Dudley J, Nei M, Kumar S. MEGA4: Molecular Evolutionary Genetics Analysis (MEGA) software version 4.0. Mol Biol Evol 2007;24:1596-9.

[39] Saitou N, Nei M. The neighbor-joining method: a new method for reconstructing phylogenetic trees. Mol Biol Evol 1987;4:406-25.

[40] Rozen S, Skaletsky HJ. Primer3 on the WWW for general users and for biologist programmers. MIMB 2000;132:365-86.

[41] Pfaffl MW. A new mathematical model for relative quantification in real-time RTPCR. Nucleic Acids Res 2001;29:e45.

[42] Nicolas P, Vanhoye D, Amiche M. Molecular strategies in biological evolution of antimicrobial peptides. Peptides 2003;24:1669-80.

[43] Tennessen JA. Molecular evolution of animal antimicrobial peptides: widespread moderate positive selection. J Evol Biol 2005;18:1387-94.

[44] Padhi A, Verghese B. Evidence for positive Darwinian selection on the hepcidin gene of Perciform and Pleuronectiform fishes. Mol Divers 2007;11:119-30. 
[45] Tennessen JA. Enhanced synonymous site divergence in positively selected vertebrate antimicrobial peptide genes. $J$ Mol Evol 2005;61:445-55.

[46] Fernandes JMO, Ruangsri J, Kiron V. Atlantic cod piscidin and its diversification through positive selection. PloS One 2010;5:e9501.

[47] Sunyer JO, Lambris JD. Evolution and diversity of the complement system of poikilothermic vertebrates. Immunol Rev 1998;166:39-57.

[48] Shike H, Lauth X, Westerman ME, Ostland VE, Carlberg JM, van Olst JC,et al. Bass hepcidin is a novel antimicrobial peptide induced by bacterial challenge. European Eur J Biochem 2002;269:2232-7.

[49] Douglas SE, Gallant JW, Liebscher RS, Dacanay A, Tsoi SCM. Identification and expression analysis of hepcidin-like antimicrobial peptides in bony fish. Dev Comp Immunol 2003;27:589-601.

[50] Chen SL, Xu MY, Ji XS, Yu GC, Liu Y. Cloning, characterization, and expression analysis of hepcidin gene from red sea bream (Chrysophrys major). Antimicrob Agents Chemother 2005;49:1608-12.

[51] Rodrigues PNS, Vázquez-Dorado S, Neves JV, Wilson JM. Dual function of fish hepcidin: response to experimental iron overload and bacterial infection in sea bass (Dicentrarchus labrax). Dev Comp Immunol 2006;30:1156-67.

[52] Cho YS, Lee SY, Kim KH, Kim SK, Kim DS, Nam YK. Gene structure and differential modulation of multiple rockbream (Oplegnathus fasciatus) hepcidin isoforms resulting from different biological stimulations. Dev Comp Immunol 2009;33:46-58.

[53] Cuesta A, Meseguer J, Esteban MA. The antimicrobial peptide hepcidin exerts an important role in the innate immunity against bacteria in the bony fish gilthead seabream. Fish Shellfish Immunol 2008;45:2333-42.

[54] Li W, Sun WX, Tang F, Li CP, Liu CD. Molecular characterization and expression analysis of a hepcidin gene from rice field eel (Monopterus albus). Afr J Biotechnol 2011;10:7953-61. 
[55] Solstad T, Larsen AN, Seppola M, Jørgensen T Ø. Identification, cloning and expression analysis of a hepcidin cDNA of the Atlantic cod (Gadus morhua L.). Fish Shellfish Immunol 2008;25:298-310.

[56] Nemeth E, Preza GC, Jung CL, Kaplan J, Waring AJ, Ganz T. The N-terminus of hepcidin is essential for its interaction with ferroportin: structure-function study. Blood 2006;107:328-33.

[57] Yang M, Chen B, Cai JJ, Peng H, Cai L, Yuan JJ, et al. Molecular characterization of hepcidin AS-hepc2 and AS-hepc6 in black porgy (Acanthopagrus schlegelii):

Expression pattern responded to bacterial challenge and in vitro antimicrobial activity. Comp Biochem Physiol B 2011;158:155-63.

[58] Chiou PP, Lin CM, Bols NC, Chen TT. Characterization of virus/double-stranded RNA-dependent induction of antimicrobial peptide hepcidin in trout macrophagues. Dev Comp Immunol 2007;31:1297-309.

[59] Alvarez-Hernandez X, Liceaga J, McKay IC, Brock JH. Induction of hypoferremia and modulation of macrophage iron metabolism by tumor necrosis factor. Lab Invest 1989;61:319-22.

[60] Koca SS, Isik A, Ustundag B, Metin K, Aksoy K. Serum pro-hepcidin levels in rheumatoid arthritis and systemic lupus erythematosus. Inflammation 2008;31:146-53.

[61] Cai L, Cai JJ, Liu HP, Fan DQ, Peng H, Wang KJ. Recombinant medaka (Oryzias melastigmus) pro-hepcidin: Multifunctional characterization. Comp Biochem Physiol B. In press 2011.

[62] Nemeth E, Tuttle MS, Powelson J, Vaughn MB, Donovan A, Ward DM, et al. Hepcidin regulates cellular iron efflux by binding to ferroportin and inducing its internalization. Science 2004;306:2090-3.

[63] Mietzner TA, Morse SA. The role of iron-binding proteins in the survival of pathogenic bacteria. Annu Rev Nut 1994;14:471-93.

[64] Drakesmith H, Prentice A. Viral infection and iron metabolism. Nat Rev Microbiol $2008 ; 6: 541-52$. 


\section{Figure legends}

Figure 1. ORF sequence of turbot Hepcidin-2. The amino acid sequence corresponding to the predicted signal peptide is boxed, the prodomain region is in cursive letters and the mature peptide is shaded in grey colour. Polymorphic nucleotide and amino acid positions are marked in bold. Intron positions and lengths are indicated by vertical lines.

Figure 2. Alignment showing the identities between both turbot hepcidins. Identical amino acids are shaded in grey color. Hashes indicate the positions of the eight conserved Cys residues.

Figure 3. An exon-intron diagram showing the organization of turbot Hepcidin-2 gene.

Figure 4. (A) Amino acid alignment of turbot hepcidins with hepcidin peptides from other vertebrates. The signal peptides are underlined, the mature peptides are shaded in grey colour and the eight conserved Cys are indicated with hashes. (B) Phylogenetic tree of hepcidins from different vertebrates based on the complete amino acid sequence. The tree was constructed using the neighbour-joining method and gaps were completely deleted. Numbers indicate the percentage of bootstrapping after 1,000 replications.

Figure 5. (A) Hep-1 and (B) Hep-2 constitutive expression in various tissues of juvenile turbot. Fold-change units were calculated by dividing the normalized expression values for each tissue by the normalized expression values obtained in the organ presenting the lower expression level for each hepcidin (brain in both cases). (C) Relative proportions of turbot hepcidin types in different tissues calculated taking into account the normalized values of each hepcidin in the same tissue.

Figure 6. Expression of Hep-1 (A) and Hep-2 (B) in head kidney and liver at 3, 8, 24 and $72 \mathrm{~h}$ after Aeromonas salmonicida subsp. salmonicida challenge (black bars). Asterisks above the bars indicate significant differences between each sampling point and the corresponding control (PBS-injected groups) (white bars), and asterisks over lines show statistical significant differences across the different sampling points $(p<$ $0.05)$.

Figure 7. Expression of Hep-1 (A) and Hep-2 (B) in head kidney and liver at 3, 8, 24 and $72 \mathrm{~h}$ after Viral Haemorrhagic Septicaemia virus infection (black bars). Asterisks above the bars indicate significant differences between each sampling point and the 
corresponding control (MEM $+2 \%$ FBS $+\mathrm{P} / \mathrm{S}$-injected groups) (white bars), and asterisks over lines show statistical significant differences across the different sampling points $(p<0.05)$.

Figure 8. Expression of Hep-1 (A) and Hep-2 (B) in head kidney and liver at 3, 8, 24 and $72 \mathrm{~h}$ after Iron-dextran administration (black bars). Asterisks above the bars indicate significant differences between each sampling point and the corresponding control (PBS-injected groups) (white bars), and asterisks over lines show statistical significant differences across the different sampling points $(p<0.05)$.

Figure 9. Expression of Hep-1 (A) and Hep-2 (B) in head kidney and liver at $24 \mathrm{~h}$ after administration of three different Iron-dextran doses (black bars). Asterisks above the bars indicate statistical significant differences between each sampling point and the corresponding control (PBS-injected groups) (white bars) $(p<0.05)$.

\section{Tables}

Table 1. Primer sequences used in the ORF amplification and expression analysis.

\begin{tabular}{|c|c|c|c|}
\hline & Gene & Primer & Sequence $\left(5^{\prime}-3^{\prime}\right)$ \\
\hline \multirow[t]{4}{*}{ ORF amplification } & Hepcidin-1 & Hepcidin Comp F1 & CTCAAAATGAAGGCATTCAG \\
\hline & & Hepcidin Comp R1 & GAATCCTCAGAACTTGCAGC \\
\hline & Hepcidin-2 & AMP Comp F1 & ATGAAGACTCTCACCGTTGCAG \\
\hline & & AMP Comp R1 & CATGGCTGTTGGAGCAGGAATTC \\
\hline \multirow[t]{6}{*}{ q-PCR } & Hepcidin-1 & Hepc.-F3 & CGAGTCACATCAGGCAGAAG \\
\hline & & Hepc.-R4 & TCCTCAGAACTTGCAGCAGA \\
\hline & Hepcidin-2 & AMP prec $2 \mathrm{~F}$ & ATGAAGACTCTCACCGTTGC \\
\hline & & AMP prec2 $\mathrm{R}$ & TTCTGTCTGTTACTCGGCATC \\
\hline & EF1 alpha & T1-F2 & GGAGGCCAGCTCAAAGATGG \\
\hline & & $\mathrm{T} 1-\mathrm{R} 2$ & ACAGTTCCAATACCGCCGATTT \\
\hline
\end{tabular}




\section{*Highlights}

A novel hepcidin-like antimicrobial peptide (Hep-2) was characterized in turbot A. salmonicida and VHSV challenge affect the expression of both turbot hepcidins Iron overload only induces the expression of Hep-1

A differential role of turbot hepcidins in suggested in this paper 
1 ATGAAGACTCTCACCGTTGCAGTCGCAGTGGCCGTCGTGCTCGCCTTC

1 \begin{tabular}{|llllllllllllllll|}
\hline$M$ & $K$ & $\mathrm{~T}$ & $\mathrm{~L}$ & $\mathrm{~T}$ & $\mathrm{~V}$ & $\mathrm{~A}$ & $\mathrm{~V}$ & $\mathrm{~A}$ & $\mathrm{~V}$ & $\mathrm{~A}$ & $\mathrm{~V}$ & $\mathrm{~V}$ & $\mathrm{~L}$ & $\mathrm{~A}$ & $\mathrm{~F}$ \\
\hline
\end{tabular}

49 ATTTGGATKCAGGAGAGCGCT GCCACATTCCACGGGGCACAACAGCCG

17 \begin{tabular}{|llllllllllllllll}
\hline$I$ & $W$ & $M / I$ & $Q$ & $E$ & $S$ & $A$ & $A$ & $T$ & $F$ & $H$ & $G$ & $A$ & $Q$ & $Q$ & $P$
\end{tabular}

97 GAGGAGGCGGTGAGCAATRAGGATCCAGCTGCTGATCCTCAGGAGACA

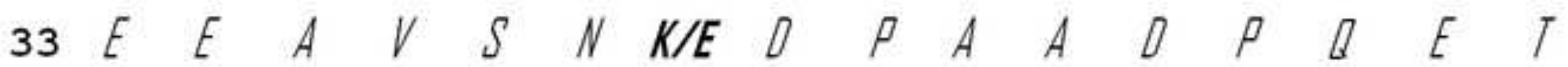

145 CCGGTGGACTCGTGGATG|ATGCCGAGTAACAGACAGAAGCGCGGCATG

$\begin{array}{lllllllllllllllll}49 & P & V & D & S & W & M & M & P & S & N & R & Q & K & R & G & M\end{array}$

193 AAGTGCAAGTTTTGCTGCAACTGCYGCAACWTKAATGGCTGCGGCRTG

$\begin{array}{llllllllllllllllll}65 & K & C & K & F & C & C & N & \complement & C / R & N & F / L / L / M & N & G & \complement & G & M / V\end{array}$

241 TGCTGCGATTTCTGA

$81\lceil\quad\lceil\quad D \quad F \quad-$ 
Figure 2
Click here to download high resolution image

Hepcidin-1

Hepoidin-2

Hepcidin-1

Hepcidin-2
MKAFSIAVAVTLVLAFVCILES SAVPFPGVQELEEAGSNDTPAAAHOET SMEPWTVPSH I MKTLTVAVAVAVVLAFIWMQES -AATFHGAQQPEEAVSNED PAADPQETPVDSWMMP---

Mature peptide

\section{RQKRQSHISLCRWCCNCCKAYKGCGFCCKF 90}

-SNRQKRGMKCKFCCNCCNLN-GCGVCCDF 84

$\# \# \# \# \# \quad \# \quad \#$

Mature peptide 


\section{EXON 1}

EXON 2

EXON 3

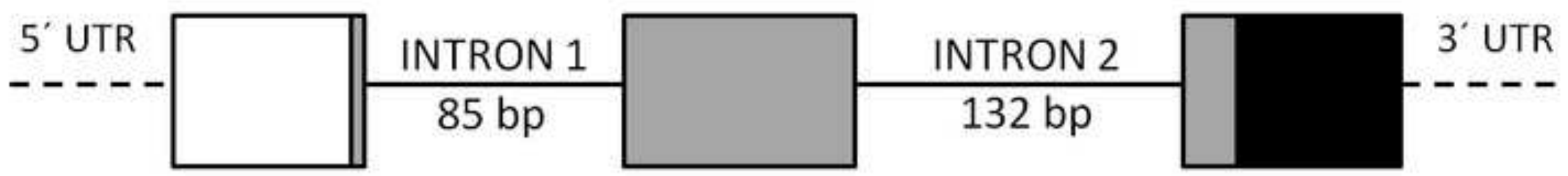

$\square \quad$ Signal peptide

$\square$ Prodomain

Mature peptide 


\section{Click here to download high resolution image}

Soophehalmus maximis Mep-1 scophthalniat maximus Hog-2

Dazalichehyz olivacess Hop-Jr! Payaliehelyys olivaceus Hepo-JF? Puntirs sarase

rotalaris puncescas

Siniperoa chuatsi

Salmo salat

Oneorhynohus nekis

Sparats allata

Hotone ehryaopa

Danio zorio

Dienerazehus 1abrax

Xenopus cropicalis Hep-

Xenepas eropienIis Hep-2

Crocodylum an avensis

Rateu: norvegiou

Mas masculas

Equar oabalitus

pan troglodyter

Hono sapions

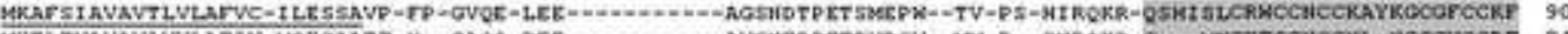

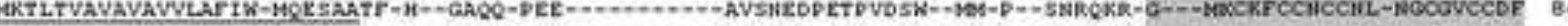
GKTFSAAVTVAVWWEIC-TCOSSATS-P--EVQE-LEE - - ACGIDTDMa MTKT WRa W

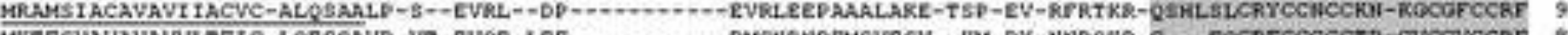
GKFPSVAVAVAVUTPIC-LQRSSAVP-VT-EVQE-LEE-

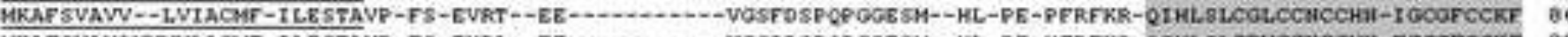

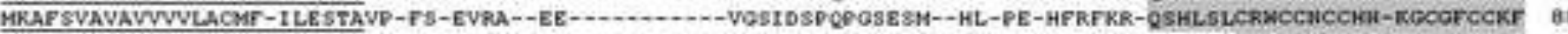

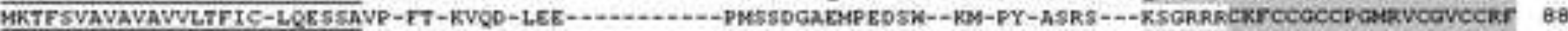

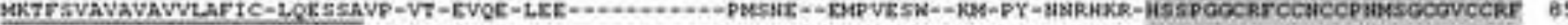

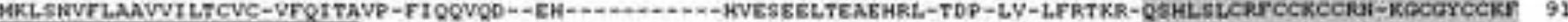

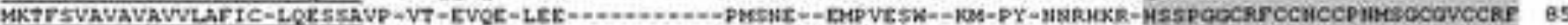

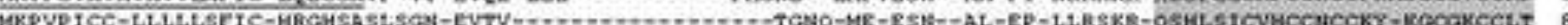
UKX AKaILLCC-LLLLLETCMXI

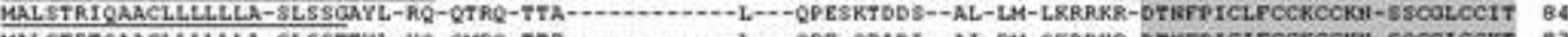
MALSTRTQAACLLLLLLLA-SLSSTTYL-HQ-GASR-TTE-...

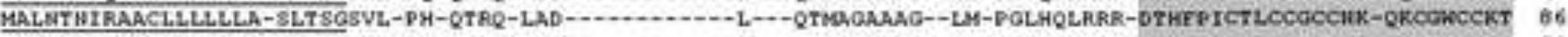

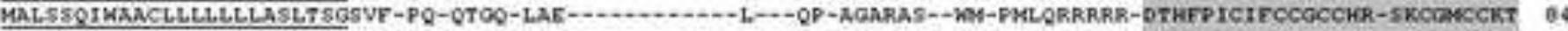

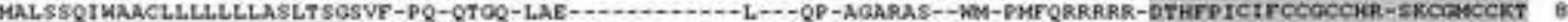

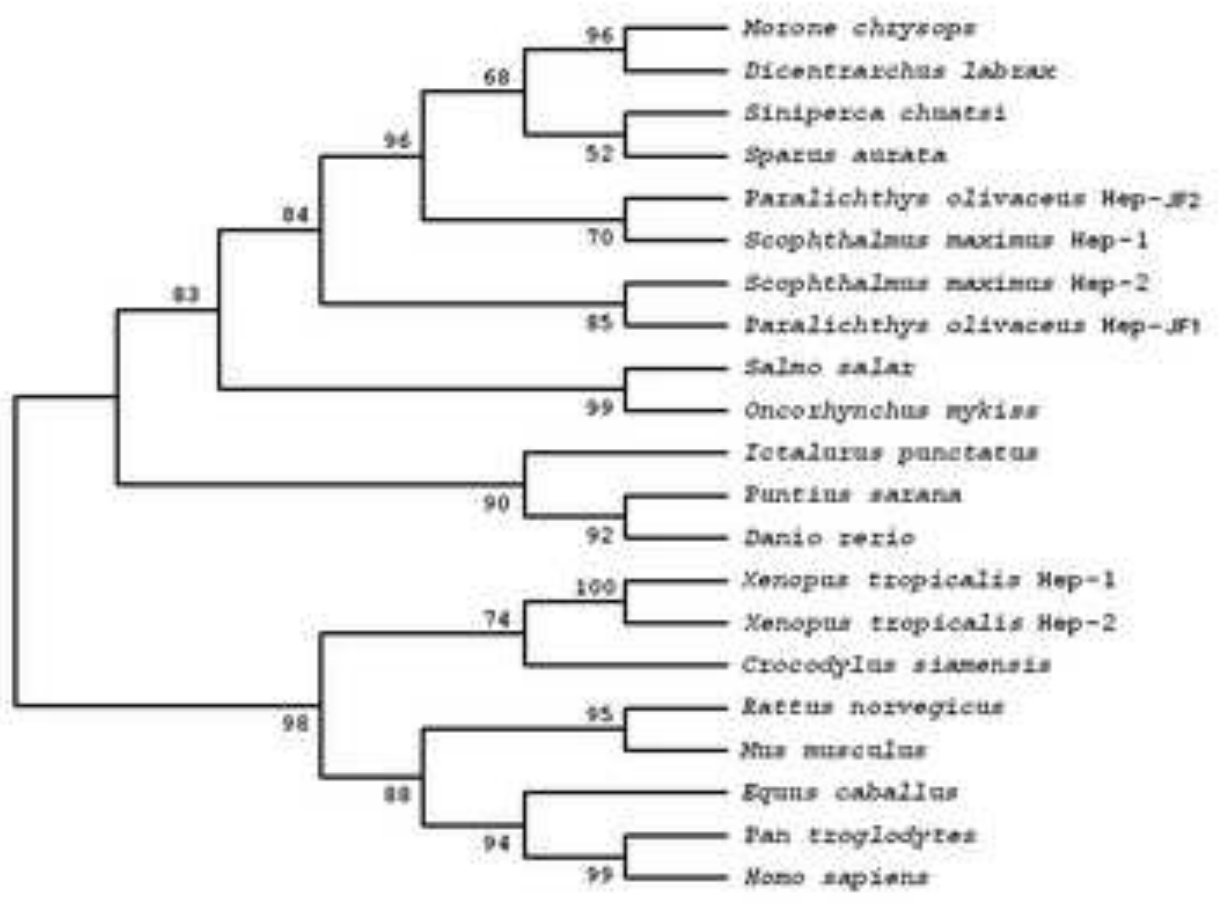



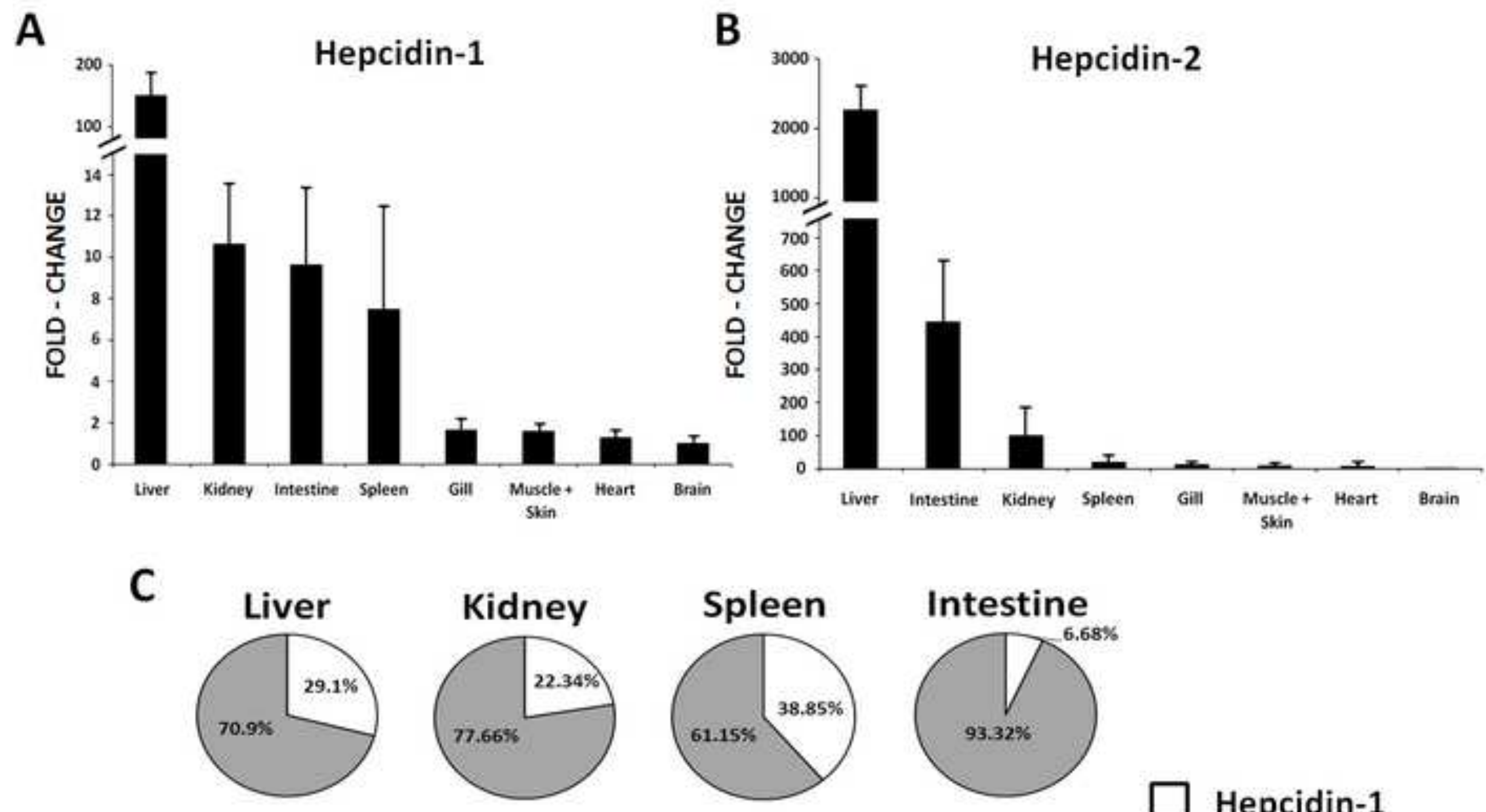

$\square$ Hepcidin-1
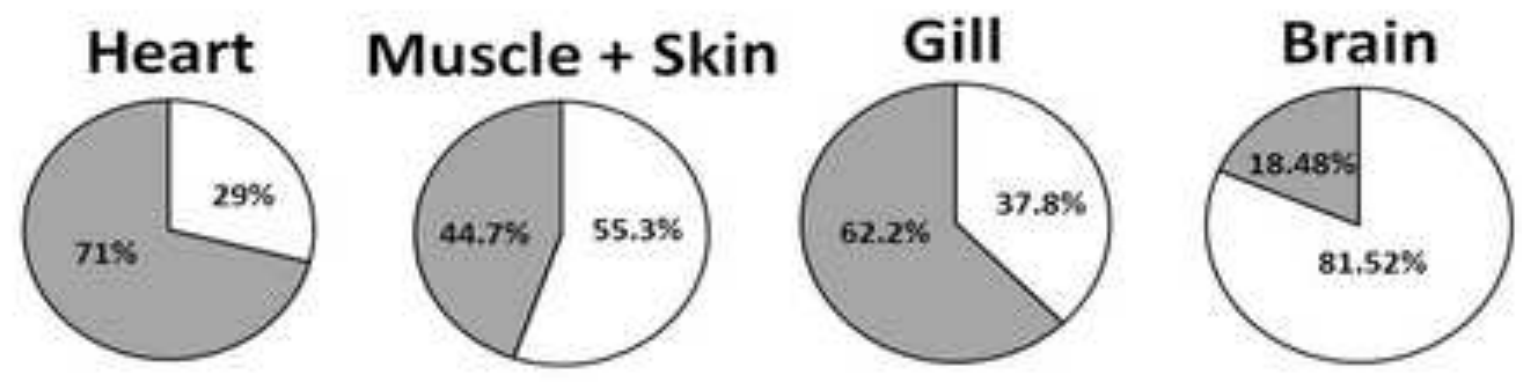

Hepcidin-2 
A

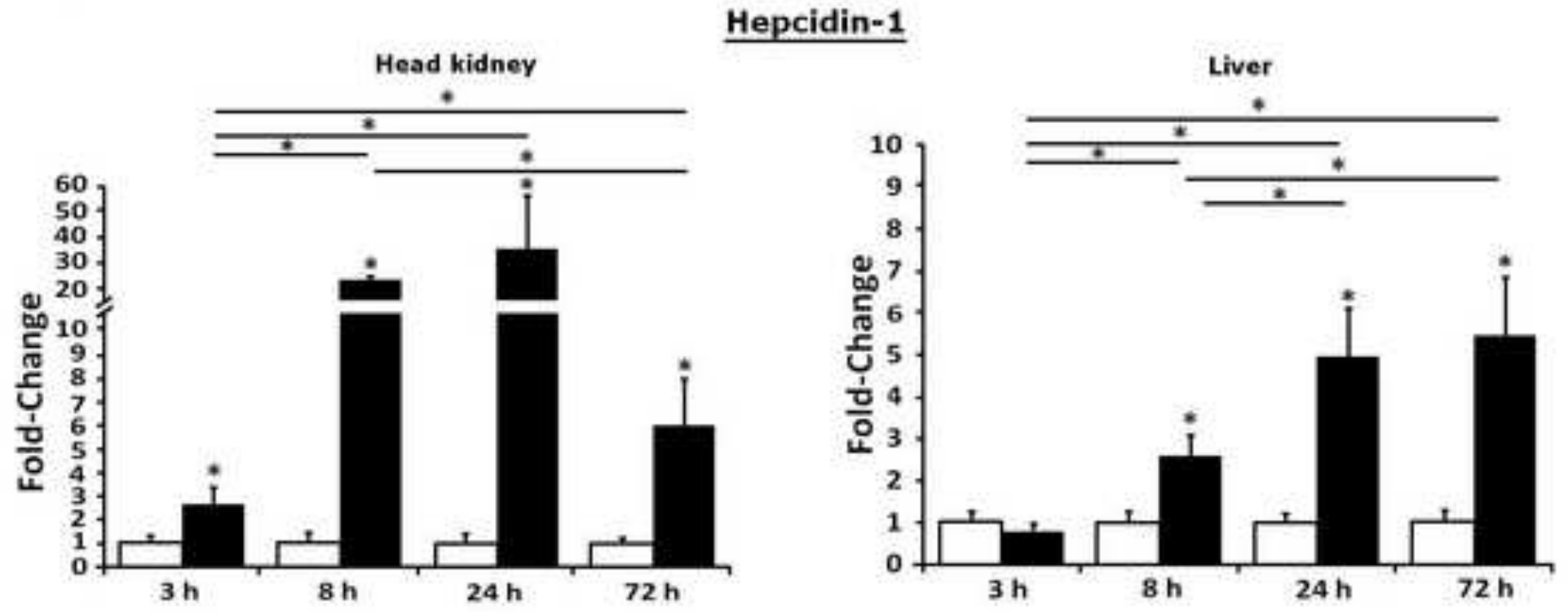

B

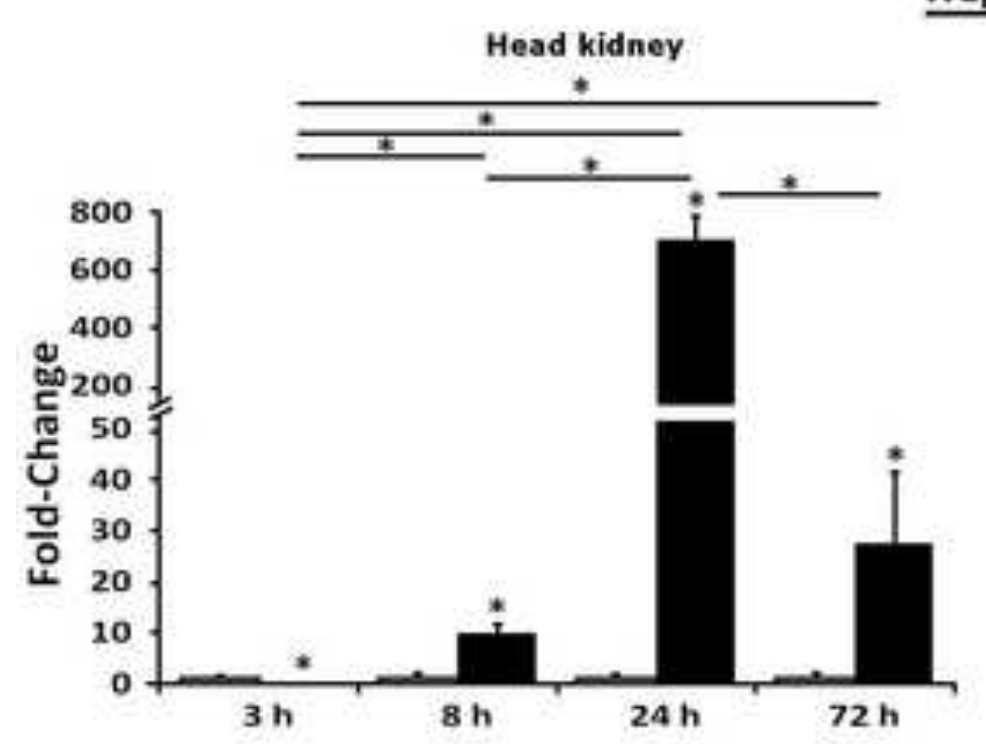

Hepcidin-2

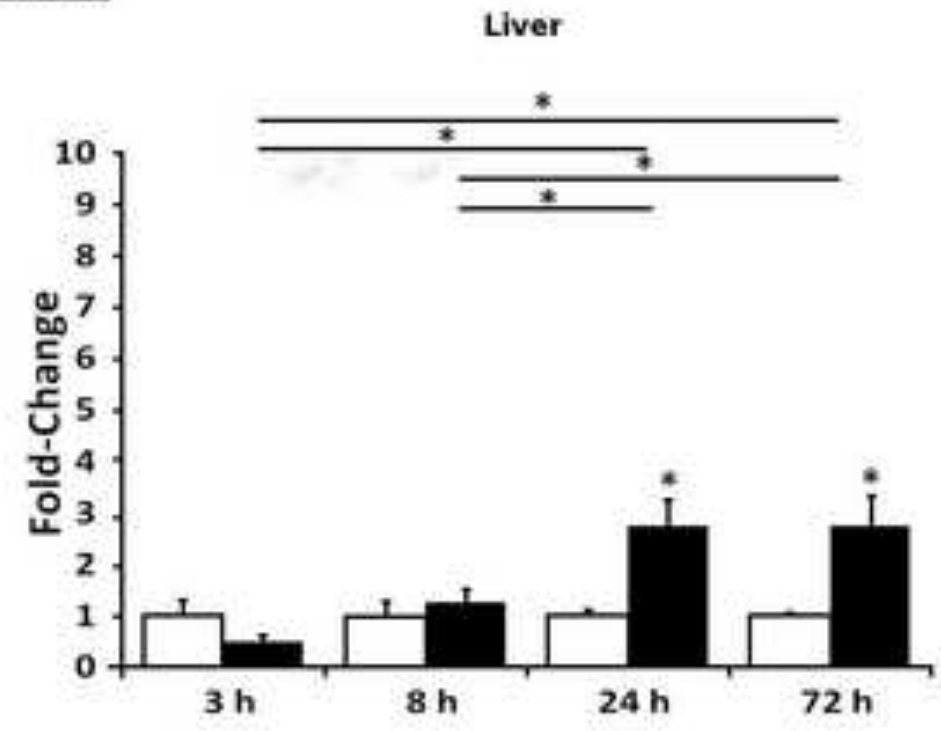


Click here to download high resolution image

A

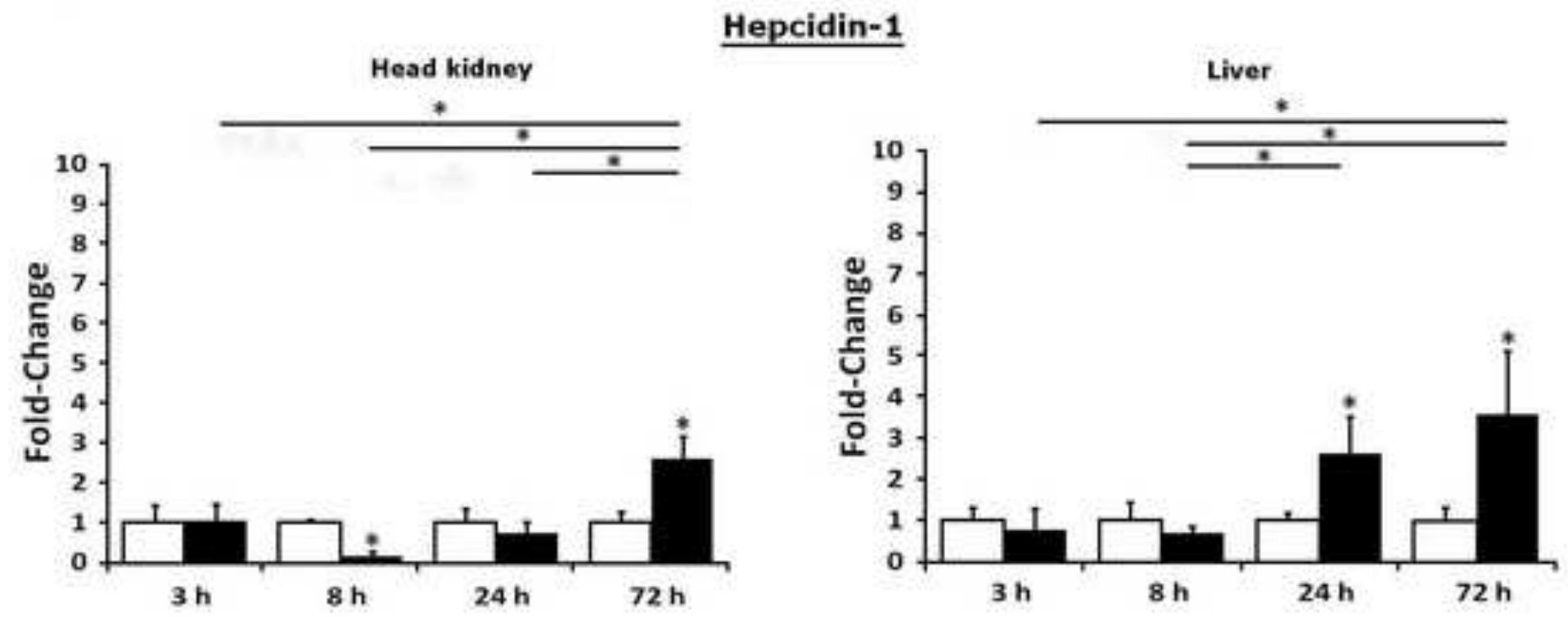

B

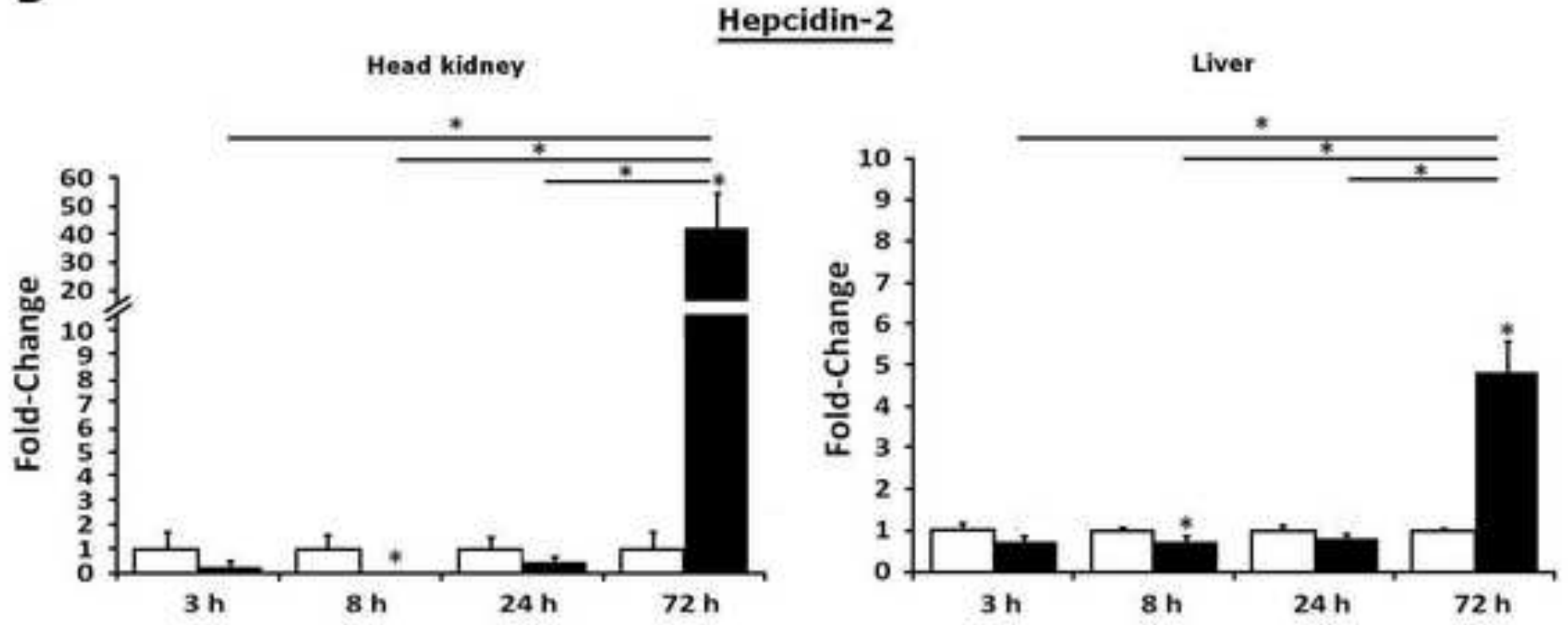


A

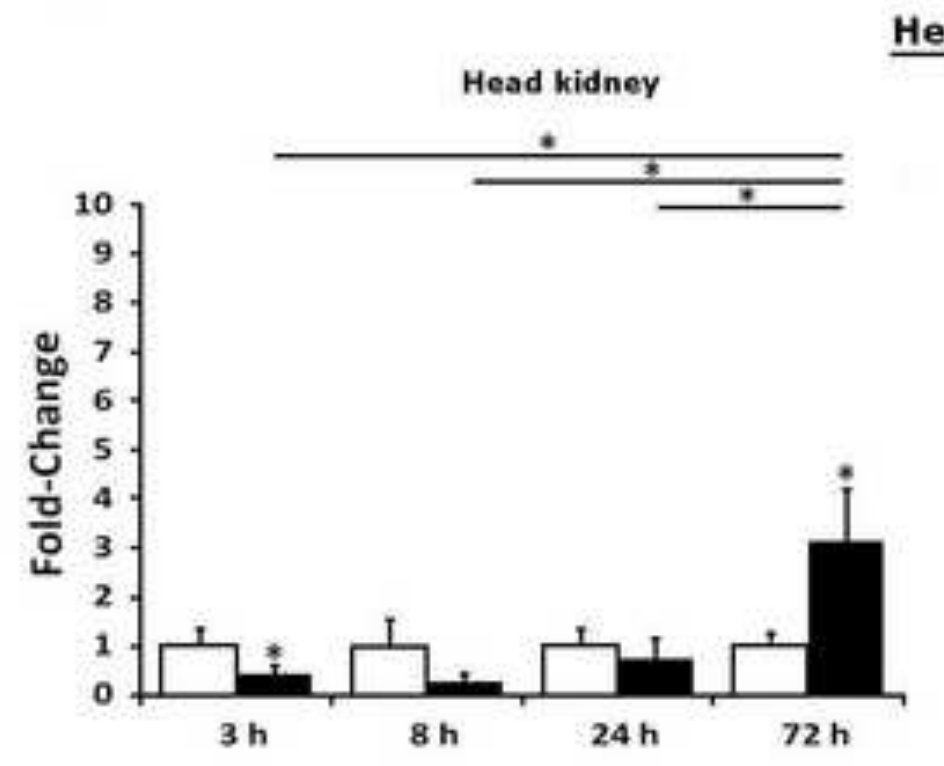

Hepcidin-1

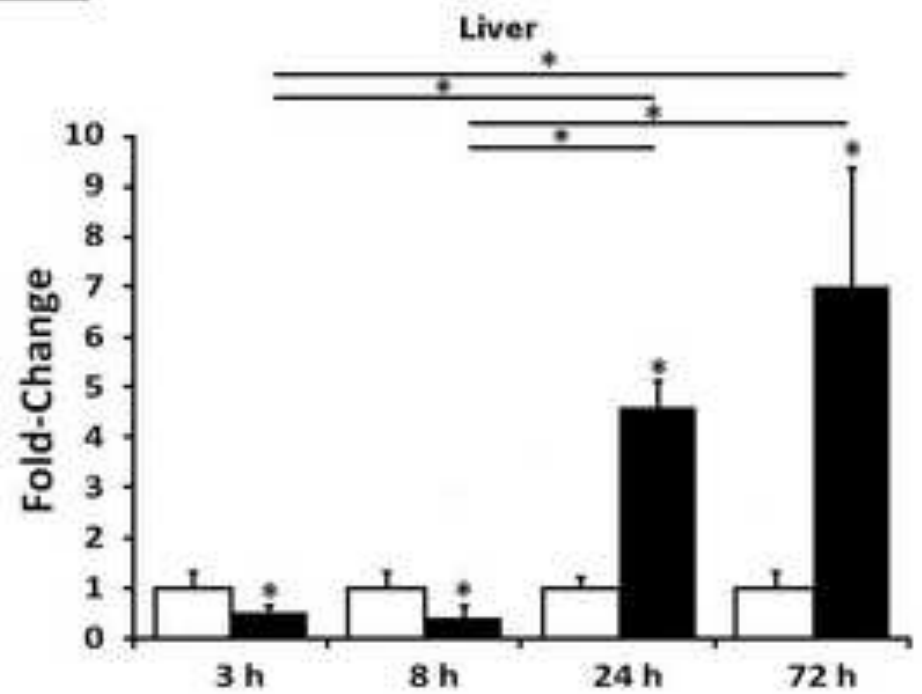

B

Hepcidin-2

Head kidney

Liver
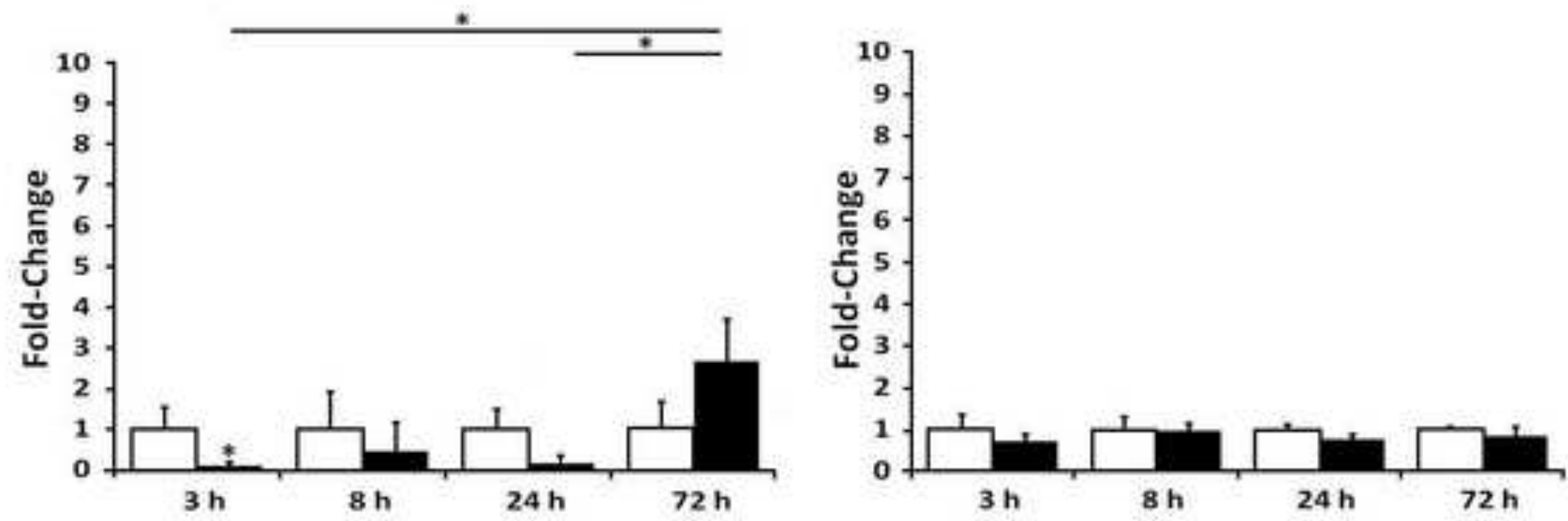
Click here to download high resolution image

A

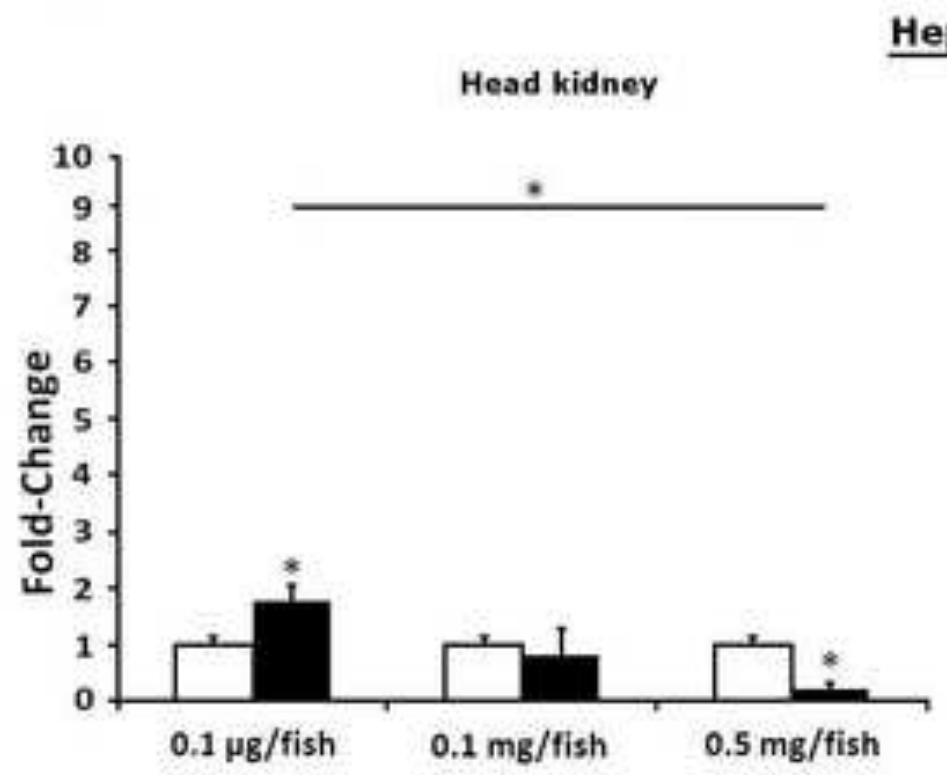

Hepcidin-1

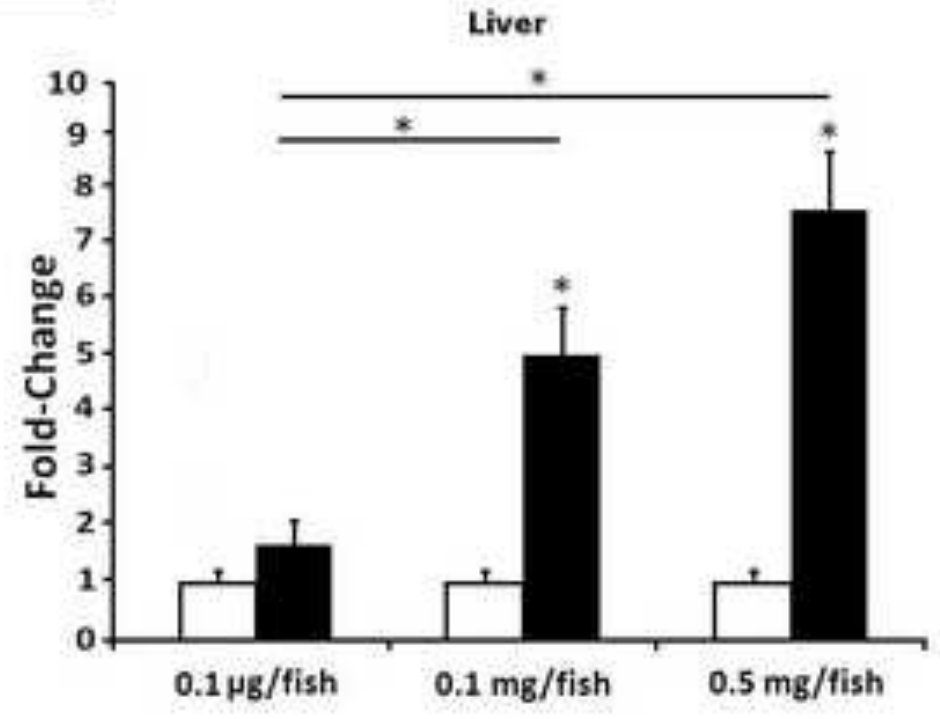

B

Head kidney

\section{Hepcidin-2}
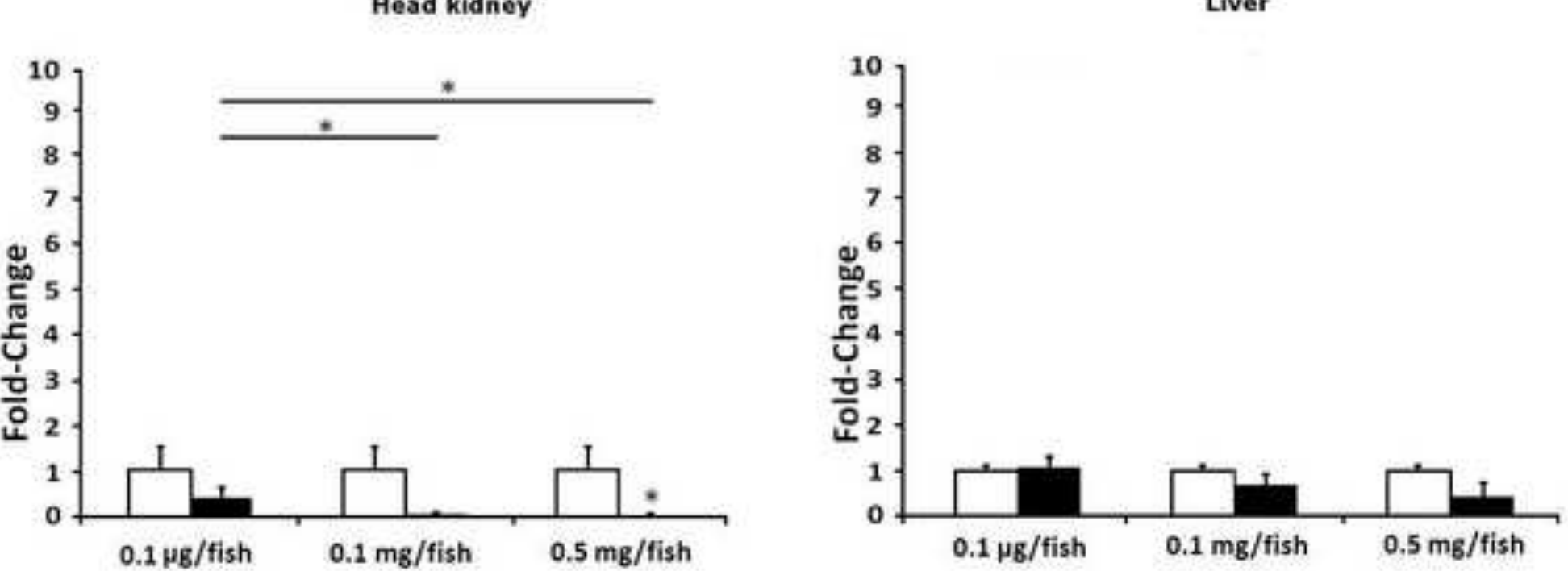